\title{
Lactobacillus equicursoris sp. nov., isolated from the faeces of a thoroughbred racehorse
}

\section{Correspondence \\ Hidetoshi Morita morita@azabu-u.ac.jp}

\author{
Hidetoshi Morita, ${ }^{1}$ Mitsuharu Shimazu, ${ }^{1}$ Hiroshi Shiono, ${ }^{1}$ Hidehiro Toh, ${ }^{2}$ \\ Fumihiko Nakajima, ${ }^{3}$ Hiroaki Akita, ${ }^{3}$ Misako Takagi, ${ }^{4}$ Hideto Takami, ${ }^{5}$ \\ Masaru Murakami, ${ }^{1}$ Toshio Masaoka, ${ }^{1}$ Soichi Tanabe ${ }^{6}$ \\ and Masahira Hattori ${ }^{7}$
}

\author{
${ }^{1}$ School of Veterinary Medicine, Azabu University, 1-17-71 Fuchinobe, Sagamihara, Kanagawa \\ 229-8501, Japan \\ ${ }^{2}$ RIKEN Advanced Science Institute, 1-7-22 Suehiro, Tsurumi, Yokohama, Kanagawa 230-0045, \\ Japan \\ ${ }^{3}$ Northern Farm, 275 Hayakita-genbu, Abira-cho, Yufutsu-gun, Hokkaido 059-1432, Japan \\ ${ }^{4}$ Crossfield-Bio Inc., 1-1-20 Higashi-nihonbashi, Chuo, Tokyo 103-0004, Japan \\ ${ }^{5}$ Microbial Genome Research Group, Japan Agency of Marine-Earth Science and Technology, 2-15 \\ Natsushima, Yokosuka, Kanagawa 237-0061, Japan \\ ${ }^{6}$ Graduate School of Biosphere Science, Hiroshima University, 1-4-4 Kagamiyama, Higashi- \\ Hiroshima, Hiroshima 739-8528, Japan \\ ${ }^{7}$ Graduate School of Frontier Sciences, University of Tokyo, 5-1-5 Kashiwanoha, Kashiwa, Chiba \\ 277-8562, Japan
}

\begin{abstract}
We previously isolated five strains of putative lactobacilli from the faeces of a thoroughbred horse (a 4-year-old male). Of the five strains, four were identified as members of existing Lactobacillus species; however, sequence analysis of the $16 \mathrm{~S}$ rRNA gene revealed that the fifth isolate, $\mathrm{DI}^{\top}{ }^{\top}$, showed approximately $97 \%$ identity (1325/1366 bp) with the type strain of Lactobacillus delbrueckii. Therefore, we considered the possibility that $\mathrm{DI} 7 \mathrm{O}^{\top}$ represents a novel species of the genus Lactobacillus. Cells of strain DI70 ${ }^{\top}$ were Gram-stain-positive, catalase-negative, nonspore-forming, non-motile rods. In phylogenetic trees constructed on the basis of 16S rRNA gene sequences, strain $\mathrm{DI} 70^{\top}$ formed a subcluster in the L. delbrueckii phylogenetic group and was closely related to $L$. delbrueckii, Lactobacillus crispatus and Lactobacillus jensenii. However, analysis of DNA-DNA relatedness showed that $\mathrm{DI} 70^{\top}$ was genetically distinct from its phylogenetic relatives. The isolate also exhibited distinct biochemical and physiological characteristics when compared with its phylogenetic relatives. It required anaerobic conditions for growth on agar medium. The results indicate that isolate $\mathrm{DI} 7 \mathrm{O}^{\top}$ indeed represents a novel species of the genus Lactobacillus, for which we propose the name Lactobacillus equicursoris sp. nov. The type strain is $\mathrm{DI}^{\top}{ }^{\top}$ (=JCM $\left.14600^{\top}=\mathrm{DSM} 19284^{\top}\right)$.
\end{abstract}

The genus Lactobacillus includes a large number of species of lactic acid bacteria. Lactobacilli are normal inhabitants of the gastrointestinal tracts of many mammals. The diversity of lactobacilli in the contents of the equine gastrointestinal tract and faeces has been investigated using culturing and molecular profiling methods, respectively ( $\mathrm{Al}$ Jassim et al., 2005; Endo et al., 2007). The species

The GenBank/EMBL/DDBJ accession number for the 16S rRNA gene sequence of strain $\mathrm{D} 170^{\top}$ is $\mathrm{AB} 290830$.

$16 \mathrm{~S}$ rRNA gene sequence-based maximum-parsimony and maximumlikelihood trees and details of DNA-DNA hybridization results are available as supplementary material with the online version of this paper.
Lactobacillus equi, L. hayakitensis and L. equigenerosi were first isolated from the equine gastrointestinal tract/faeces (Morotomi et al., 2002; Morita et al., 2007b; Endo et al., 2008). L. equi and L. hayakitensis are placed within the Lactobacillus salivarius phylogenetic group and L. equigenerosi within the Lactobacillus reuteri phylogenetic group. In the present study, isolate $\mathrm{DI} 70^{\mathrm{T}}$, from faeces of a thoroughbred horse (Morita et al., 2009), is shown to represent a novel species belonging to the Lactobacillus delbrueckii phylogenetic group.

In 2006, we isolated five strains of putative lactobacilli in a study on the strains of lactobacilli inhabiting the faeces of a 
healthy thoroughbred horse (a 4-year-old male). Of the five strains, four have been identified as strains of Lactobacillus mucosae, L. johnsonii, L. equigenerosi and L. buchneri (Morita et al., 2009). Although the fifth isolate, DI70 ${ }^{\mathrm{T}}$, formed a subcluster in the $L$. delbrueckii phylogenetic group, this strain was not identified.

Blood liver (BL) agar plates (Eiken Chemical Co.) and anaerobic bacterial culture medium (ABCM broth; Eiken Chemical Co.) were used for cell culture. Strain DI70 ${ }^{\mathrm{T}}$ was cultured anaerobically at $37{ }^{\circ} \mathrm{C}$ in ABCM broth and on BL agar plates for 24 and $72 \mathrm{~h}$, respectively. L. delbrueckii JCM $1002^{\mathrm{T}}$, Lactobacillus crispatus JCM $1185^{\mathrm{T}}$ and Lactobacillus jensenii DSM $20557^{\mathrm{T}}$ were obtained from the Japan Collection of Microorganisms and the Deutsche Sammlung von Mikroorganismen und Zellkulturen $\mathrm{GmbH}$.

The 16S rRNA gene sequence (1486 bp) of strain DI70 ${ }^{\mathrm{T}}$ was determined by using previously described methods (Morita et al., 2007b). The closest known relatives of the isolate were determined by performing database searches, and the sequences of closely related species were retrieved from public databases. Multiple alignments of the sequences were carried out using CLUSTAL $\mathrm{W}$ (Thompson et al., 1994). Distance matrices for the aligned sequences were calculated using the two-parameter method described by Kimura (1980). We used the neighbour-joining method to construct a phylogenetic tree (Saitou \& Nei, 1987) and estimated the robustness of the individual branches by performing bootstrapping analysis with 1000 replicates (Felsenstein, 1985). Phylogenetic trees were also constructed using the maximum-likelihood (Cavalli-Sforza \& Edwards, 1967) and maximum-parsimony (Kluge \& Farris, 1969) methods with PHYLIP version 3.66. Analysis of the 16S rRNA gene revealed that DI70 ${ }^{\mathrm{T}}$ had the highest sequence similarity to the type strains of $L$. delbrueckii (97\%; 1325/1366 bp), L. crispatus (94\%, 1310/1387 bp) and $L$. jensenii $(95 \%, 1230 / 1288 \mathrm{bp})$. In the phylogenetic tree constructed by the neighbour-joining method, DI70 ${ }^{\mathrm{T}}$ formed a subcluster in the $L$. delbrueckii phylogenetic group (Schleifer \& Ludwig, 1996; Hammes \& Hertel, 2006) (Fig. 1). We obtained identical tree topologies in the maximum-parsimony and maximum-likelihood analysis (see Supplementary Fig. S1 in IJSEM Online). L. delbrueckii, L. johnsonii, L. crispatus and Lactobacillus amylovorus, strains of which have been isolated from the contents of the equine gastrointestinal tract by Bailey et al. (2003), Al Jassim et al. (2005) and Morita et al. (2009), belong to the L. delbrueckii phylogenetic group. Although we could not isolate other strains of the same species as DI70 ${ }^{\mathrm{T}}$ in this study, we found that strains RA2120, RA2062 and RA2066 (GenBank accession nos AY445128, AY445129 and AY445130; Al Jassim et al., 2005) showed greater identity $(97.5-97.6 \%, 1353-1354 / 1388 \mathrm{bp})$ to the $16 \mathrm{~S}$ rRNA gene sequence of DI70 ${ }^{\mathrm{T}}$ than to that of the type strain of Lactobacillus agilis (97.0\%, 1325/1366 bp). These strains were isolated from the equine gastrointestinal tract (stomach and rectum; $\mathrm{Al}$ Jassim et al., 2005) and were thus

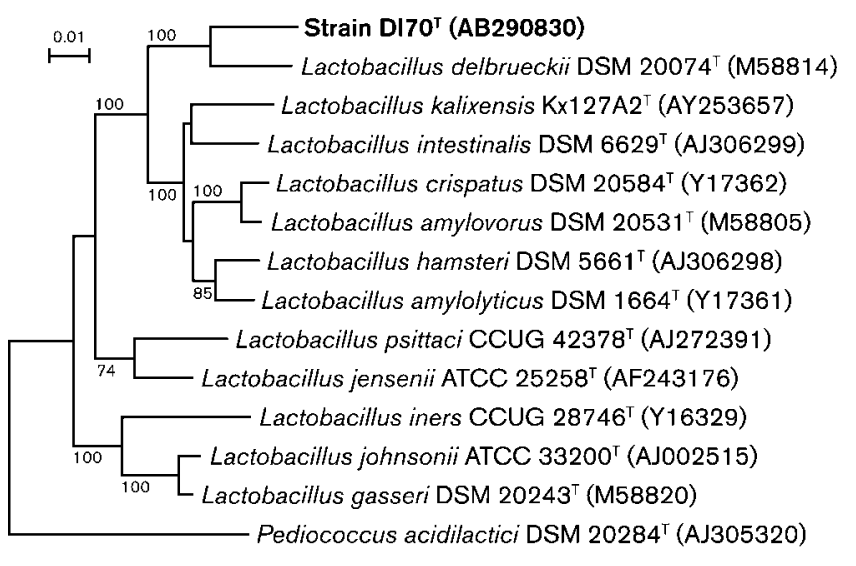

Fig. 1. Phylogenetic relationships between strain $D I 70^{\top}$ and species in the $L$. delbrueckii phylogenetic group, as determined on the basis of sequence analysis of the 16S rRNA gene. The tree was constructed using the neighbour-joining method. The sequence of Pediococcus acidilactici DSM $20284^{\top}$ was used as an outgroup. Bar, 0.01 substitutions per nucleotide position.

of the same origin as DI70 ${ }^{\mathrm{T}}$. This suggests that members of this subcluster mainly inhabit the equine gastrointestinal tract.

DNA-DNA relatedness between DI70 ${ }^{\mathrm{T}}$ and three closely related type strains was determined by previously described methods (Ezaki et al., 1990). We used the method described by Morita et al. (2007a) to isolate the genomic DNA of strain DI70 ${ }^{\mathrm{T}}$, L. delbrueckii JCM $1002^{\mathrm{T}}$, L. crispatus JCM $1185^{\mathrm{T}}$ and L. jensenii DSM 20557 ${ }^{\mathrm{T}}$. DNA-DNA relatedness values are shown in Supplementary Table S1. Each value was less than the $70 \%$ cut-off point recommended for species differentiation (Stackebrandt \& Goebel, 1994).

The $\mathrm{G}+\mathrm{C}$ content of strain DI70 ${ }^{\mathrm{T}}$ was determined in three separate trials by using previously described methods (Morita et al., 2007b). The DNA G $+\mathrm{C}$ content of strain DI70 ${ }^{\mathrm{T}}$ was $48.3 \mathrm{~mol} \%$; this differed from the values of 35.0 and $36.0 \mathrm{~mol} \%$ obtained for the closely related L. crispatus JCM $1185^{\mathrm{T}}$ and L. jensenii DSM $20557^{\mathrm{T}}$ (Table 1 ). However, the DNA G+C content of DI70 ${ }^{\mathrm{T}}$ was similar to that of L. delbrueckii JCM $1002^{\mathrm{T}}$ (50.3 mol\%).

The biochemical and physiological characteristics of strain DI70 ${ }^{\mathrm{T}}$ were determined by using previously described methods (Mitsuoka, 1969). The detailed characteristics of the isolate are provided in the species description, and these characteristics were compared with those of the phylogenetic relatives $L$. delbrueckii JCM $1002^{\mathrm{T}}$, L. crispatus JCM $1185^{\mathrm{T}}$ and L. jensenii DSM $20557^{\mathrm{T}}$ (Table 1). The isolate was an obligately homofermentative lactic acid bacterium that could produce D-lactic acid from D-glucose. Although the three phylogenetic relatives formed colonies under aerobic conditions, DI70 ${ }^{\mathrm{T}}$ did not. Strain DI70 ${ }^{\mathrm{T}}$ was distinguished from L. delbrueckii JCM $1002^{\mathrm{T}}$ by its pattern 
Table 1. Physiological characteristics of strain $\mathrm{DI}^{\top} \mathrm{O}^{\top}, L$. delbrueckii JCM $1002^{\top}$, L. crispatus JCM $1185^{\top}$ and $L$. jensenii DSM $20557^{\top}$

Strains: 1, DI70 ${ }^{\mathrm{T}}$ (data from this study); 2, L. delbrueckii JCM $1002^{\mathrm{T}}$ (Rogosa \& Hansen, 1971); 3, L. crispatus JCM $1185^{\mathrm{T}}$ (Cato et al., 1983); 4, L. jensenii DSM $20557^{\mathrm{T}}$ (Gasser et al., 1970; Kandler \& Weiss, 1986). All strains are obligately homofermentative, produce no gas from D-glucose and possess L-Lys-D-Asp peptidoglycan type of the cell wall. All strains are negative for the following characters: growth at $15{ }^{\circ} \mathrm{C}$, catalase activity and fermentation of arabinose, Dribose, D-xylose, rhamnose, sorbitol and melezitose. $\mathrm{G}+\mathrm{C}$ contents were determined by HPLC. +, Positive; -, negative; w, weakly positive; ND, no data available.

\begin{tabular}{|lcccc|}
\hline Characteristic & $\mathbf{1}$ & $\mathbf{2}$ & $\mathbf{3}$ & $\mathbf{4}$ \\
\hline Lactic acid isomer(s) & $\mathrm{D}$ & $\mathrm{D}$ & $\mathrm{DL}$ & $\mathrm{D}$ \\
Aerobic growth & - & + & + & + \\
Growth at $45{ }^{\circ} \mathrm{C}$ & $\mathrm{W}$ & + & + & - \\
Fermentation of: & & & & \\
$\quad$ Gluconate & - & - & $\mathrm{ND}$ & $\mathrm{ND}$ \\
Fructose & + & $\mathrm{W}$ & + & + \\
Galactose & + & $\mathrm{W}$ & + & + \\
Mannose & + & $\mathrm{W}$ & + & + \\
Cellobiose & + & - & + & + \\
Lactose & + & + & + & - \\
Salicin & + & - & + & + \\
Melibiose & $\mathrm{W}$ & - & $\mathrm{W}$ & - \\
Trehalose & - & - & - & + \\
Raffinose & $\mathrm{W}$ & - & + & - \\
Mannitol & + & - & - & + \\
Starch & $\mathrm{W}$ & - & + & $\mathrm{ND}$ \\
DNA G+C content $(\mathrm{mol} \%)$ & 48.3 & 50.3 & 35.0 & 36.1 \\
& & & & \\
\hline
\end{tabular}

of acid production from carbohydrates. Using the HPLC method of Komagata \& Suzuki (1987), the peptidoglycan type in the cell wall of strain DI70 ${ }^{\mathrm{T}}$ was L-Lys-L-Asp, as was the case with the three phylogenetic relatives. Anaerobic conditions were essential for growth of strain DI70 ${ }^{\mathrm{T}}$.

The experimental data suggest that the isolate can be assigned to the genus Lactobacillus on the basis of its phylogenetic position; however, the unique physiological and biochemical characteristics of the isolate and DNADNA relatedness results distinguish it from its phylogenetic relatives. Thus, the isolate represents a novel species, for which we propose the name Lactobacillus equicursoris sp. nov.

\section{Description of Lactobacillus equicursoris sp. nov.}

Lactobacillus equicursoris ( $\mathrm{e}^{\prime}$ qui.cur'so.ris. L. n. equus a horse; L. gen. n. cursoris of a runner or racer; N.L. gen. n. equicursoris of a racing horse, referring to the isolation of the type strain from faeces of a thoroughbred racehorse).

Cells are Gram-stain-positive, non-motile, curved rods, $0.5-1.0 \times 10-30 \mu \mathrm{m}$, and they usually grow singly. Colonies on BL agar after incubation under anaerobic conditions for
2 days at $37{ }^{\circ} \mathrm{C}$ are beige, smooth and approximately $0.7-$ $1.0 \mathrm{~mm}$ in diameter. Homofermentative, obligately anaerobic and catalase-negative. Produces D-lactic acid from Dglucose. Produces acid from glucose, fructose, galactose, mannose, cellobiose, lactose, salicin and mannitol, and produces acid weakly from melezitose, raffinose and starch. Grows well at $30-40{ }^{\circ} \mathrm{C}$ and slowly at $45{ }^{\circ} \mathrm{C}$; does not grow at 15 or $50{ }^{\circ} \mathrm{C}$. The peptidoglycan type of the cell wall is L-Lys-L-Asp and the DNA G + C content of the type strain is $48.3 \mathrm{~mol} \%$.

The type strain is DI70 ${ }^{\mathrm{T}}\left(=\mathrm{JCM} 14600^{\mathrm{T}}=\mathrm{DSM} 19284^{\mathrm{T}}\right)$, isolated from faeces of a thoroughbred racehorse collected in 2006 .

\section{Acknowledgements}

We thank all the concerned staff members at the Ikee Stable of the Japan Racing Association (JRA) for supplying the faeces of the thoroughbred racehorse 'Deep Impact', the triple crown winner of JRA in 2005. This research was supported by a fund from the Japan Racing Horse Association (JRHA) and the 2007-2009 Azabu Academic Frontier Project-Matching Fund Subsidy for Private Universities.

\section{References}

Al Jassim, R. A. M., Scott, P. T., Trebbin, A. L., Trott, D. \& Pollitt, C. C. (2005). The genetic diversity of lactic acid producing bacteria in the equine gastrointestinal tract. FEMS Microbiol Lett 248, 75-81.

Bailey, S. R., Baillon, M.-L., Rycroft, A. N., Harris, P. A. \& Elliott, J. (2003). Identification of equine cecal bacteria producing amines in an in vitro model of carbohydrate overload. Appl Environ Microbiol 69, 2087-2093.

Cato, E. P., Moore, W. E. C. \& Johnson, J. L. (1983). Synonymy of strains of "Lactobacillus acidophilus" group A2 (Johnson et al. 1980) with the type strain of Lactobacillus crispatus (Brygoo and Aladame 1953) Moore and Holdman 1970. Int J Syst Bacteriol 33, 426-428.

Cavalli-Sforza, L. L. \& Edwards, A. W. F. (1967). Phylogenetic analysis. Models and estimation procedures. Am J Hum Genet 19, 233-257.

Endo, A., Okada, S. \& Morita, H. (2007). Molecular profiling of Lactobacillus, Streptococcus, and Bifidobacterium species in feces of active racehorses. J Gen Appl Microbiol 53, 191-200.

Endo, A., Roos, S., Satoh, E., Morita, H. \& Okada, S. (2008). Lactobacillus equigenerosi sp. nov., a coccoid species isolated from faeces of thoroughbred racehorses. Int J Syst Evol Microbiol 58, 914918.

Ezaki, T., Saidi, S. M., Liu, S.-L., Hashimoto, Y., Yamamoto, H. \& Yabuuchi, E. (1990). Rapid procedure to determine the DNA base composition from small amounts of Gram-positive bacteria. FEMS Microbiol Lett 67, 127-130.

Felsenstein, J. (1985). Confidence limits on phylogenies: an approach using the bootstrap. Evolution 39, 783-791.

Gasser, F., Mandel, M. \& Rogosa, M. (1970). Lactobacillus jensenii sp. nov., a new representative of the subgenus Thermobacterium. J Gen Microbiol 62, 219-222.

Hammes, W. P. \& Hertel, C. (2006). The genera Lactobacillus and Carnobacterium. In The Prokaryotes, 3rd edn, vol. 4, pp. 320-403. Edited by M. Dworkin, S. Falkow, E. Rosenberg, K. H. Schleifer \& E. Stackebrandt. New York: Springer. 
Kandler, O. \& Weiss, N. (1986). Genus Lactobacillus Beijerinck 1901, $212^{\mathrm{AL}}$. In Bergey's Manual of Systematic Bacteriology, vol. 2, pp. 12091234. Edited by P. H. A. Sneath, N. S. Mair, M. E. Sharpe \& J. G. Holt. Baltimore: Williams \& Wilkins.

Kimura, M. (1980). A simple method for estimating evolutionary rates of base substitutions through comparative studies of nucleotide sequences. J Mol Evol 16, 111-120.

Kluge, A. G. \& Farris, J. S. (1969). Quantitative phyletics and the evolution of anurans. Syst Zool 18, 1-32.

Komagata, K. \& Suzuki, K. (1987). Lipid and cell-wall analysis in bacterial systematics. Methods Microbiol 19, 161-207.

Mitsuoka, T. (1969). Vergleichende Untersuchungen über die Lactobazillen aus den Faeces von Menschen, Schweinen und Hühnern. Zentralbl Bakteriol [Orig] 210, 32-51 (in German).

Morita, H., Kuwahara, T., Ohshima, K., Sasamoto, H., Itoh, K., Hattori, M., Hayashi, T. \& Takami, H. (2007a). An improved DNA isolation method for metagenomic analysis of the microbial flora of the human intestine. Microbes Environ 22, 214-222.

Morita, H., Shiratori, M., Murakami, M., Takami, H., Kato, Y., Endo, A., Nakajima, F., Takagi, M., Akita, H. \& other authors (2007b). Lactobacillus hayakitensis sp. nov., isolated from intestines of healthy thoroughbreds. Int J Syst Evol Microbiol 57, 2836-2839.

Morita, H., Nakano, A., Shimazu, M., Toh, H., Nakajima, F., Nagayama, M., Hisamatsu, S., Kato, Y., Takagi, M. \& other authors
(2009). Lactobacillus hayakitensis, L. equigenerosi and L. equi, predominant lactobacilli in the intestinal flora of healthy thoroughbreds. Anim Sci J 80, 339-346.

Morotomi, M., Yuki, N., Kado, Y., Kushiro, A., Shimazaki, T., Watanabe, K. \& Yuyama, T. (2002). Lactobacillus equi sp. nov., a predominant intestinal Lactobacillus species of the horse isolated from faeces of healthy horses. Int J Syst Evol Microbiol 52, 211214.

Rogosa, M. \& Hansen, P. A. (1971). Nomenclatural considerations of certain species of Lactobacillus Beijerinck. Request for an Opinion. Int J Syst Bacteriol 21, 177-186.

Saitou, N. \& Nei, M. (1987). The neighbor-joining method: a new method for reconstructing phylogenetic trees. Mol Biol Evol 4, 406425.

Schleifer, K. H. \& Ludwig, W. (1996). Phylogeny of the genus Lactobacillus and related genera. Syst Appl Microbiol 18, 461-467.

Stackebrandt, E. \& Goebel, B. M. (1994). Taxonomic note: a place for DNA-DNA reassociation and 16S rRNA sequence analysis in the present species definition in bacteriology. Int J Syst Bacteriol 44, 846849.

Thompson, J. D., Higgins, D. G. \& Gibson, T. J. (1994). Clustal W: improving the sensitivity of progressive multiple sequence alignment through sequence weighting, position-specific gap penalties and weight matrix choice. Nucleic Acids Res 22, 4673-4680. 